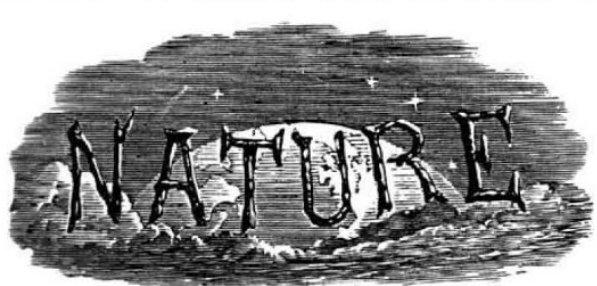

SATURDAY, OCTOBER 2, I926.

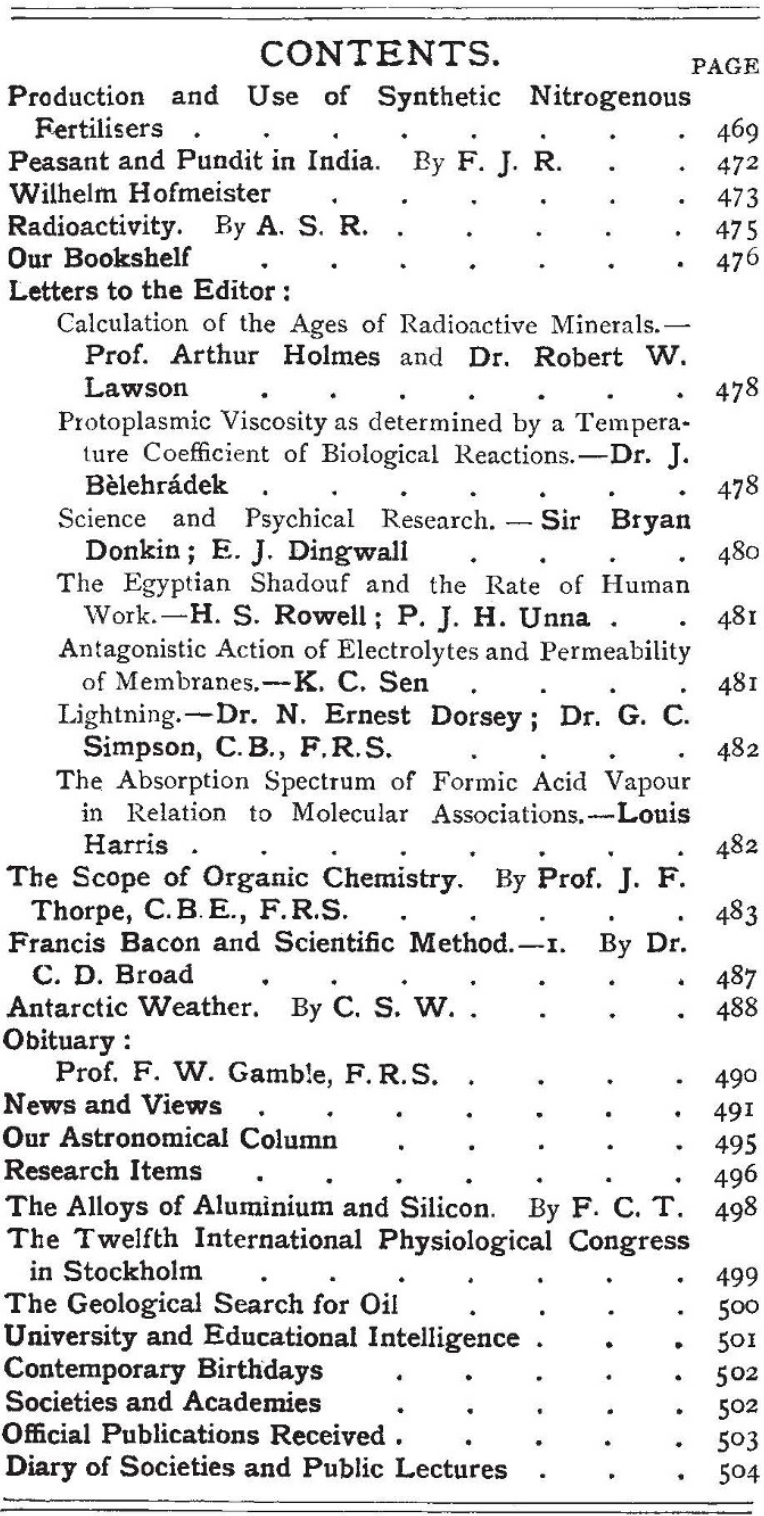

Editorial and Publishing Offices:

MACMILLAN \& CO., LTD.,

ST. MARTIN'S STREET, LONDON, W.C.2.

Editorial communications should be addressed to the Editor. Advertisements and business letters to the Publishers.

Telephone Number: GERRARD 8830.

Telegraphic Address: PHUSIS, WESTRAND, LONDON.

\section{Production and Use of Synthetic Nitrogenous Fertilisers.}

A

MONG the factors that are shaping the course of nations to-day, few are more important than the possession or control of raw materials. Nature, in her perverse way, has not only made men very unequal in character, energy, and ability, but she has also distributed so capriciously their means of sustenance and development that no civilised country is, or can expect to be, entirely self-supporting in the economic sense. There are many signs that the question of raw materials for food and industry will profoundly affect, if not dominate, international relationships. The United States is crying aloud for sources of supply of rubber, potash, mercury, manganese, long-staple cotton, and sisal ; Germany, by her loss of territories in Europe and overseas, has become more dependent than ever upon foreign countries for a host of basic raw materials ; Italy, Belgium, and Japan are asking the League of Nations to appoint a committee to consider the subject.

The question is, however, not entirely an economic one ; its ramifications penetrate many spheres of human activity, including that of science and its applications, for chemistry, physics, physiology, botany, and entomology are all playing their parts in alleviating the consequences of Nature's haphazard distribution of the necessaries of life and progress. From chemistry and physics we may, perhaps, expect most, for are they not showing us every day how to satisfy our primary needs by fabricating the raw materials of food, of clothing, and of shelter from such simple materials as air, water, fuel, and vegetation?

Of all the basic needs of man, food is the most essential ; and, as Sir Daniel Hall recently reminded us at Oxford, the old problem of its supply still awaits solution. Man ever tends to multiply beyond his means of subsistence; land suitable for agriculture is limited in extent ; its fertility declines, and must not only be restored but also increased to meet our ever-growing needs. Civilisation, through the sanitary authority, has made us abandon the economic practice (followed by Germany during the War, and by China from time immemorial) of returning to the soil the unassimilated plant nutrients of our food; and as other organic manures are strictly limited in amount, the only solution is to manufacture fertilisers from natural products. Fortunately for us all, the continued application of fertilisers does not, as was formerly believed, sicken the soil, provided they are scientifically applied; and the raw materials of their manufacture are very abundant, though some of them are very unequally distributed over the earth. The occurrence

NO. 2970, VOL. II 8 ] 
of potash is very localised, but the deposits are enormous, Germany and the Upper Rhine being estimated to contain no less than 21,000 million tons of crude potash salts situated at workable depths. Phosphate deposits are more numerous, although the life of the most important of them has been estimated at from twentyone to seventy years ; there are, however, vast deposits that are poor in grade or badly situated. Apart from the Chilean nitrate-beds, which have a definitely limited life, and the wonder-workings of the nitrogenfixing bacteria, the world is ill-supplied with natural nitrogenous fertilisers, but the chief raw material of these fertilisers--nitrogen-is extraordinarily abundant: no less than eight tons of it are present in the air over every square metre of the earth's crust ; and few human achievements can compare in importance with the recent work of physical chemists in making this mine of potential fertility available for agricultural purposes.

To Germany belongs most of the credit for having elaborated the manufacture of synthetic nitrogenous fertilisers by means of the Haber process. That process, together with the modifications due to Claude, Casale, and Fauser, consists in uniting nitrogen from the air with hydrogen from water to form ammonia; and to-day it is by far the most important of nitrogenfixation methods, the cyanamide process coming next and the arc process third. The estimated production of combined nitrogen in Germany during the fertiliser year 1925-26 (June-May) was 600,000 metric tons (equal to nearly 3 million tons of sulphate of ammonia), of which 90 per cent. was to be made by synthetic processes. Although the Haber and cyanamide processes were much used in Germany during the War, it was not until 1923-24 that Germany had sufficiently recovered from its effects to be able to export nitrogenous fertilisers ; for the year $1925-26$ her estimated exports were about $I 35,000$ tons of fixed nitrogen, equivalent to about 675,000 tons of sulphate of ammonia. Following Germany's lead, the manufacture of synthetic ammonia has been taken up in many lands, and although, in general, achievements have not so far corresponded with effort and reclame, there is no doubt that within the next decade production will attain a figure undreamed of before the year I9I4. It is satisfactory to note that, next to Germany, Great Britain is the most important producer of synthetic nitrogen compounds, an achievement that is due to the initiative and enterprise of Messrs. Brunner, Mond and Co., Ltd., through its associated company, Synthetic Ammonia and Nitrates, Ltd.

The future of the British nitrogen industry, its ability to retain the home market and to withstand foreign competition in the outlying parts of the Empire, are matters of national concern, not only in respect of the peace-time manufacture of fertilisers, but also in respect of the war-time production of nitric acid and high explosives. In Great Britain the chief source of supply of manufactured nitrogenous fertilisers has long been, and is still, the ammonia that is obtained from coal as a by-product in the manufacture of metallurgical coke and town's gas. This ammonia is converted into ammonium sulphate, which is still the most popular of manufactured nitrogenous fertilisers, and of which very large quantities are sold at home and abroad. Our total production of nitrogen as ammonium sulphate in the year $1925^{-26}$ was $429,5 \mathrm{I} 7$ tons, of which $238,6 \mathrm{II}$ tons was exported. Exports and prices, however, are falling as the result of severe German competition, and the outlook is not cheerful. At the recent International Conference on Nitrogen Propaganda in Biarritz, it was stated that the British Sulphate of Ammonia Federation, of which Synthetic Ammonia and Nitrates, Ltd., is a member, had made an arrangement with the German Nitrogen Syndicate by which new German nitrogen compounds that are suitable to English conditions would be made available to English farmers; but nothing in the nature of a quid pro quo was mentioned. Now the Germans are very active in producing new fertilisers, which play an important part in their propaganda.

Dr. J. Bueb told the conference at Biarritz that when Germans enter a foreign market they are very careful to 'push' only well-known fertilisers until they have obtained a firm foothold; then they introduce their novelties, usually mixed fertilisers, that are especially suitable to the local conditions. In r9r9-20 it was recognised in Germany that ammoniacal nitrogen could never completely replace nitric nitrogen (as in Chile saltpetre); and the hygroscopic and explosive ammonium nitrate being regarded as unsuitable, efforts were concentrated on producing mixed fertilisers like ammonium sulphate-nitrate and ammonium-potassium nitrate. To compete with Chilean nitrate, a white calcium nitrate of the same nitrogen content, but without its bad effect on 'sticky' soils, has been successfully marketed. In 1924 the manufacture of urea was started on a large scale, and this highly concentrated fertiliser ( 46 per cent. nitrogen) is selling very well, being especially valuable for tobacco, hops, vine, garden plants, meadows and pastures. Pure di-ammoniumhydrogen phosphate ('Diammonphos'), and a mixture of it with ammonium sulphate ('Leunaphos'), are among the chief products of the wellknown 'Badische' company; whilst a compound fertiliser containing nitrogen, phosphoric acid, and potash in the ratio $\mathrm{I}: 0.75: \mathrm{I}$ has been specially worked out for sale in China under the name of 'Leunaphosphate.' Variety of form, low price, and intensive

NO. 2970, VOL. I I 8 ] 
propaganda are the outstanding features of the rapidly expanding German trade in fertilisers.

With regard to the security of the British home market, it appears highly probable that Synthetic Ammonia and Nitrates, Ltd., will come to an arrangement with the German Nitrogen Syndicate whereby spheres of influence will be defined and selling prices will be fixed and adjusted in ways advantageous to both. Failing the conclusion of such an arrangement, or in the event of its future collapse if made, competitive ability will depend upon quality, manner of marketing, production costs, selling policy and salesmanship. On the score of quality we need entertain no fear. British goods are not always best, as the Government post-mark asserts (though they may be always the best to buy), but in the case of chemical products made by a firm of the standing of Brunner, Mond and Co. there is no doubt that they can hold their own against all comers. In the matter of producing costs there is much less certainty. The cost of labour and fuel, together with paralysing taxation, constitute at present enormous handicaps to cheap production; and it is unlikely that any Government would succeed in restricting foreign competition under the provisions of the Safeguarding of Industries Act. On the other hand, it is understood that Synthetic Ammonia and Nitrates, Ltd., has effected a number of improvements and economies in the Haber process ; it commands a personnel, financial and administrative as well as technical, that is second to none; and it has ample capital resources.

Competition at home is not to be feared, for synthetic nitrogen compounds will be produced at a cost which, in the event of unrestricted competition, would oust by-product ammonium compounds from the market. Both coke-ovens and gas-works will have to toe the line set by the nitrogen factory. The gas companies will continue to produce sulphate of ammonia, because they will not be allowed to turn their poisonous gasliquor into streams and estuaries; and what they lose on the swings of ammonia they will make up on the roundabouts of gas and other residuals. Coke-oven works will suffer an important loss of revenue, so that the price of metallurgical coke may rise, and with it the prices of iron and steel. The home industry will therefore be able to present a solid front to the foreigners who would invade the home market; but if that market is to be preserved, producing costs must be kept low by all possible means; and if labour is refractory we must cheapen overhead costs by extending sales, the possibilities of which are very considerable. The recent appointment by Synthetic Ammonia and Nitrates, Ltd., of Sir Frederick Keeble to take charge of research into the application of synthetic nitrogenous compounds to agricultural purposes, and to be director of propaganda, is of especial significance, for it shows that the company is fully aware of the possibilities of the application of science and scientific method to the problems of industry, and of the value of trained experience in organising propaganda among potential consumers.

Among the more promising new outlets for nitrogenous fertilisers is their application to meadow and pasture land. In the past only arable land has been fertilised in this manner, but three years ago the German manufacturers initiated a series of large-scale tests on the use of nitrogen, with or without phosphates, for grass-land, and the results have shown that the treatment is economically profitable, provided that due regard is had to the nature of the soil and the vegetation, although the increased returns are lower than in the case of arable land. The capital cost of this extension to farming practice would undoubtedly put an additional burden on the small farmer, but the constantly diminishing price of combined nitrogen, and the increasing cost of artificial feeding-stuffs, are factors that should encourage him to undertake the risk. Another possibility lies in the breeding of new types of the most important species of cultivated plants that will assimilate much larger quantities of nitrogen than existing types, and so yield much bigger crops from the same acreage. Such an achievement is held to be quite feasible, although many years may elapse before it is consummated. Further progress would result from the devising of means to retain in the soil the nitrogen that is applied to it in the form of nitrogenous fertilisers and manures. Sir John Russell estimates that under good farming conditions only about one-half of the applied nitrogen is recovered in the first year's crop, and but very little of the residual nitrogen in later crops. Such an economy would at first sight appear to be disadvantageous to the manufacturer, but the farmer would be able to extend his purchases of fertiliser and bring under intensive cultivation land which could not previously stand the cost of artificial dressings.

Quite apart, however, from novel developments of the above kind, there is no doubt that the field of consumption of nitrogenous fertilisers is capable of almost unlimited extension. Russia, Argentina, Canada, Australia, and South Africa are practically virgin fields for the use of manufactured fertilisers, whilst of all the countries that already use them, only Germany, the United States, France, Great Britain, Holland, and Italy are important consumers. The order for consumption of fertilisers of all kinds is that given; for nitrogenous fertilisers only, it is Germany (easily first), the United States, France, Great Britain, Holland, Italy, and Egypt. A better view of the present position is, however, obtained by considering the 
consumption per unit area of cultivated land. From the statistics published by the International Institute of Agriculture at Rome for nitrogen consumption in the fertiliser year I92I-22, it is seen that Holland comes first, followed closely by Germany, and then at a long interval come Egypt, Belgium, Great Britain, Japan, France, and Sweden, whilst the United States and Canada rank very low indeed.

When we consider that intensity of cultivation differs very greatly in these countries, and that experts in Germany maintain that her soil would respond to twice the quantity of fertilisers which are now applied, we obtain some idea of the great possibilities in store. There is big business in fertilisers to-day; there will be bigger business to-morrow ; and no progressive country will be able to afford to neglect provision of these basic raw materials of food production. With expansion of the world's demand for them, we may expect the chemical industry to occupy a more prominent place in the industrial world than it does to-day, and even the chemist may receive that meed of recognition for which he has been striving so long. In Germany to-day it is openly said that the I.G.- the enormous combine of chemical manufacturers--is the Government.

If Great Britain is to hold her own in the world's markets, better men must be attracted to the profession and industry of chemistry by offering more adequate rewards ; and salesmanship and propaganda, which are playing an increasingly important part in mundane affairs, must not be neglected. We must abandon the attitude of 'take it or leave it,' and study actual demands, local conditions, and the psychology of our customers. The farmer is proverbially one of the 'toughest nuts to crack.' Conservative by nature, he is also frequently regarded as simple. In reality he is very astute, although his time-reactions are slow. He is also suspicious, as he has good reason to be, because of his past experience of quack wares and of good wares sold at extortionate prices. He is apt to regard the adjective 'chemical' with grave suspicion: did not his forbears denounce nitrate of soda as 'the scourge'? He is also more resistant than the average town-dweller to the lure of printed advertisements; but he is not impervious to the advances of the well-qualified agricultural lecturer, and still less to the evidence of the demonstration plot. What does appeal to him strongly is the success of a neighbour or a rival in obtaining yields and results which he has been unable to achieve; and, of course, he is very susceptible to the argument of $l$. s. $d$. ; in other words, he should be approached through his primary instincts of positive self-feeling and acquisition. In this respect he is not markedly different from the rest of us ; as Goethe said, "Mankind progresses, but man remains the same."

\section{Peasant and Pundit in India.}

Bihar Peasant Life: being a Discursive Catalogue of the Surroundings of the People of that Province. By Sir George A. Grierson. (Prepared (in I885) under Orders of the Government of Bengal.) Second and revised edition. Pp. iv $+4+443+x v i i+\mathrm{clv}+40$ plates. (Patna: Government Printing Office, I926.) ro rupees.

R IHAR, the homeland of Buddhism, came under 3 the East India Company in $x_{7} 65$, and remained merged in Bengal until I9I2, when it reappeared as senior partner in the new province of Bihar and Orissa. In area Bihar is larger than Hungary; its population (nearly 600 to the square mile) is greater than that of Canada, Australia, and the Union of South Africa combined. Of its people, only 8 per cent. live in towns, a fact not easy for the 8o-per-cent.-urbanised Englishman to appreciate.

The Bihari peasant is reputed boorish, but a certain young civilian who landed in India in 1873 found him well worth study. There is only one way to get to know a peasant, and that is by talking to him. His language is not the language of poets and pundits, nor can it be learned from a dictionary, for many of its concepts have no equivalents in English and many of its words are as strange to literature as 'zoles ' and 'spitters' (unless he come from Devon) to the average professor of classical Greek. So it was that one of the most masterly linguists of the age became the peasant's pupil ; "every word in this book," writes the author, "has been collected from the mouths of the people." The task took seven years.

The plan of the book is modelled on a work by the late Dr. Crooke. It is a pity that the lead was not followed in every province of India ; for a better key to the life and mind of the ryot could not be proffered to the new-fledged civilian.

Sir George Grierson describes his book as a "discursive catalogue." It is more than that ; for, though intended only as a foundation for serious research, it throws in vivid relief the things that count in Indian peasant life. Its main interest centres, of course, in the land; the rich belt nearest the home, the leaner belt on the village outskirts, and the belt between; land new made and land washed away by the vagaries of rivers; soils sandy, clayey, loamy, saline, or stony; soils water-logged and soils which will not retain moisture; the ploughing and reploughing - " a hundred ploughings for cane, fifty for wheat," as they say in Gaya-the sowing, transplanting, irrigating, weeding, and watching; and then the harvest, and the division of the crops between landlord NO. 2970, VOL. I I 8] 